\title{
THEORETICAL STUDY ON 15-CROWN-5 COMPLEX WITH SOME METAL CATIONS
}

\author{
Yahmin ${ }^{1,2,}$, Harno Dwi Pranowo ${ }^{2}$, and Ria Armunanto ${ }^{2}$ \\ ${ }^{1}$ Department of Chemistry, Faculty of Mathematics and Natural Sciences, Universitas Negeri Malang, Indonesia \\ ${ }^{2}$ Department of Chemistry, Faculty of Mathematics and Natural Sciences, Universitas Gadjah Mada, \\ Sekip Utara POB.Bls. 21, Yogyakarta 55281, Indonesia
}

Received November 7, 2011; Accepted January 12, 2012

\begin{abstract}
The capability of 15-crown-5 ethers to form complexes with some metal cations $\left(\mathrm{Li}^{+}, \mathrm{Na}^{+}, \mathrm{K}^{+}, \mathrm{Zn}^{2+}, \mathrm{Cd}^{2+}\right.$ and $\mathrm{Hg}^{2+}$ ) was investigated by an ab initio quantum mechanical method. The calculations were performed at the RHF/lanl2mb level of theory. The interaction energies were used to evaluate the metal binding capability of the crown ether. The effect of nature of the metal on the binding properties was also studied. The results of the calculations showed that the interaction energy of the complexes increased in proportion with the ratio of ion charge, electronegativity and ionization potential to the cation diameter. In addition, based on the extraction distribution coefficient in the gas phase, it is found that the 15-crown-5 could not extract metal cations investigated.
\end{abstract}

Keywords: extraction; 15-crown-5; ab initio; Hartree-Fock

\section{ABSTRAK}

Kemampuan eter 15-mahkota-5 membentuk kompleks dengan beberapa kation logam $\left(\mathrm{Li}^{+}, \mathrm{Na}^{+}, \mathrm{K}^{+}, \mathrm{Zn}^{2+}, \mathrm{Cd}^{2+}\right.$ dan $\mathrm{Hg}^{2+}$ ) telah diteliti dengan menggunakan metode mekanika kuantum ab initio. Perhitungan ab initio dilakukan pada tingkat teori RHF/LANL2MB. Energi interaksi kompleks digunakan untuk menilai kemampuan eter mahkota dalam mengikat kation. Pengaruh sifat-sifat ion terhadap kekuatan interaksi juga diteliti. Hasil perhitungan menunjukkan bahwa peningkatan energi interaksi kompleks sebanding dengan rasio muatan ion, elektronegativitas dan potensial ionsisasi terhadap diameter kation. Berdasarkan nilai koefisien distribusi ekstraksi dalam fasa gas, disimpulkan bahwa eter 15-mahkota-5 tidak dapat mengekstrak kation yang diteliti dari larutan air secara langsung.

Kata Kunci: ekstraksi; eter 15-mahkota-5; ab initio; Hartree-Fock

\section{INTRODUCTION}

In recent years, a wide interest to the study of crown ether chemistry has been increased. This interest is due to the ability of crown ethers to form strong complexes with ionic species, especially metal cations. The capability of the crown ethers to bind the ionic species, make it possible to be used in many application. The crown ethers have been used in the cation extraction of radioactive waste [1-3], enhance selectivity in chromatography [4-5], and membrane transport [6].

Because of the important of the application of crown ethers, the study of crown ethers in various fields has been carried out experimentally and theoretically. Systematic experimental studies on crown ether complexes and alkali metal cations have been made since the 1990's, several years after Pederson received a Nobel Prize in crown ethers. By application the kinetic method, Maleknia and Brodbelt [7] have been studied gas-phase selectivity of the crown ether for alkali metal cations and found that the orders of selectivity were observed for alkali metal ions: 15-crown-5, $\mathrm{Li}^{+}>\mathrm{Na}^{+}>$ $\mathrm{K}^{+}>\mathrm{Cs}^{+}$; 18-crown-6, $\mathrm{Na}^{+} \geq \mathrm{K}^{+}>\mathrm{Li}^{+}>\mathrm{Rb}^{+}>\mathrm{Cs}^{+}$; and 21-crown-7, $\mathrm{K}^{+}>\mathrm{Na}^{+} \geq \mathrm{Rb}^{+}>\mathrm{Li}^{+}>\mathrm{Cs}^{+}$. By using the method of collision-induced dissociation (CID), More and colleagues [8] found a consistent increase in binding energy with decreasing cation size and increasing the size of the crown ether cavity. More and colleagues results corroborate by subsequent research conducted Anderson and colleagues [9].

Theoretical studies of the crown ether complexes with a single alkali cation $\left(\mathrm{Li}^{+}, \mathrm{Na}^{+}, \mathrm{K}^{+}, \mathrm{Rb}^{+}\right.$and $\left.\mathrm{Cs}^{+}\right)$ have been conducted by Hill et al. [10-11], Hag-Sung Kim [12], Martınez-Haya et al. [13], Yoshiya et al. [14] and Hwan Jin Kim et al [15]. The agreement between theory and collision-induced dissociation (CID) experimental cations binding enthalpies are generally good, but the differences as much as $14 \mathrm{kcal} / \mathrm{mole}$ were noted for 12-crown-4 complexes with some of the heavier cations [10]. As part of an on-going effort to develop modeling crowns ether-cation metal complexes, we devoted these studies to the complexes

* Corresponding author.

Email address : yahminoby@gmail.com

Yahmin et al. 


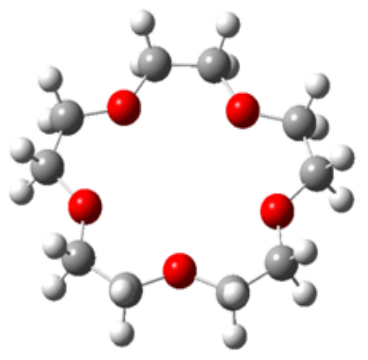

(a) Top view of 15-crown-5

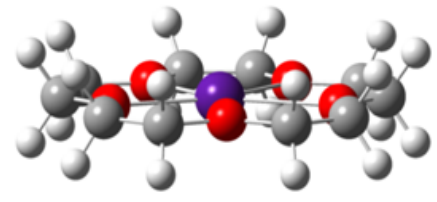

(b) Side view of $[\mathrm{M}(15 \mathrm{C} 5)]^{\mathrm{n}+}$ complex
Fig 1. Model structure of 15-crown-5 (a) and its complex (b)

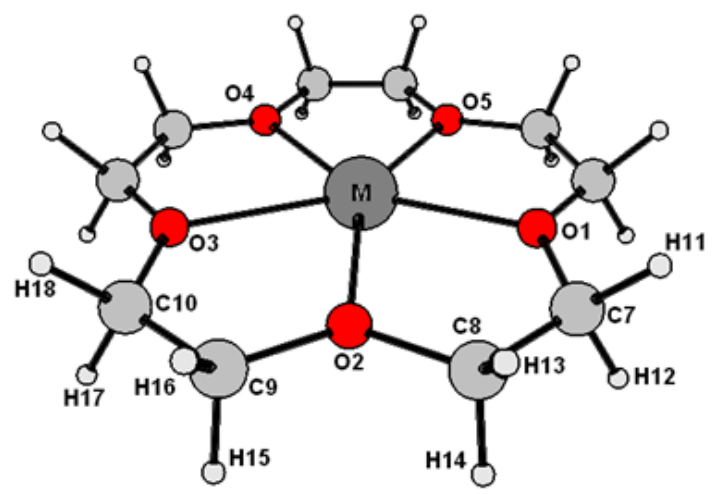

Fig 2. Structure and atomic numbering of the $[\mathrm{M}(15-$ Crown-5)] ${ }^{\text {n+ }}$ complexes

formed by ether $15-$ crown-5 with $\mathrm{Li}^{+}, \mathrm{Na}^{+}, \mathrm{K}^{+}, \mathrm{Zn}^{2+}, \mathrm{Cd}^{2+}$ and $\mathrm{Hg}^{2+}$ as we have previously studied for 12-crown-4 [16].

\section{EXPERIMENTAL SECTION}

All calculations of metal cation-crown ether complex systems were performed with the ab initio restricted Hartree-Fock method. This method is capable of providing adequately accurate structures and thermodynamical properties of different molecular system. Geometry optimization for $\mathrm{M}^{\mathrm{n}+}-15-\mathrm{Crown}-5$ complexes has been performed with lanl2mb basis set. In order to find out the most stable equilibrium structure, the complex of $15-$ crown-5 with $\mathrm{Li}^{+}, \mathrm{Na}^{+}, \mathrm{K}^{+}, \mathrm{Zn}^{2+}, \mathrm{Cd}^{2+}$ and $\mathrm{Hg}^{2+}$ were fully optimized without imposing any symmetry restrictions as implemented Gaussian 03 program. The optimized minimum energy structures of the complexes have been confirmed by the absence of any imaginary frequency in the output of calculation.

The model structure of 15 -crown- 5 was depicted in the form of three-dimensional (3D) using the Chemcraft program. Conformation of crown ethers was arranged so that the ethylene group $\left(-\mathrm{CH}_{2} \mathrm{CH}_{2}-\right)$ leads to the outside of the crown cavity and the crown ether oxygen atoms leads to the inside of the crown cavity. The top view of 15-crown-5 is shown in Fig. 1. To obtain the structural models of metal cations-crown ethers complexes, the metal cation is placed in the middle of crown cavity (Fig. 1b)

In order to study the relative stability of the 15crown-5 complexes with $\mathrm{Li}^{+}, \mathrm{Na}^{+}, \mathrm{K}^{+}, \mathrm{Zn}^{2+}, \mathrm{Cd}^{2+}$ and $\mathrm{Hg}^{2+}$ cations, a simple model reaction were used to estimate the relative interaction energy. The relative gas phase stability of the complexes was estimated as the energy for the following reaction:

$\mathrm{M}^{\mathrm{n+}}+15 \mathrm{C} 5 \rightleftharpoons[\mathrm{M}(15 \mathrm{C} 5)]^{\mathrm{n}+}, \Delta \mathrm{EkJ} / \mathrm{mol}$

where $\mathrm{M}^{\mathrm{n}+}$ denote the various cations under consideration, $15 \mathrm{C} 5$ is acronym for 15 -crown-5, and $\Delta \mathrm{E}$ is the interaction energy of the complex of 15 -crown-5 with the studied cations. In this study, the interaction energy $(\Delta E)$ reflects the interaction power between crown ethers and metal ions. Interaction energy is calculated as the difference between the energy of the complexes with the energy of crown ether molecules and metal cations. Interaction energy in this study is defined as:

$\Delta \mathrm{E}=\mathrm{E}_{\mathrm{AB}}-\mathrm{E}_{\mathrm{A}}-\mathrm{E}_{\mathrm{B}}$

In this equation, $E_{A B}$ is energy of $[M(15 C 5)]^{n+}$ complex, $E_{A}$ is energy of $15-$ crown-5, and $E_{B}$ is the energy of metal cation under consideration. These interaction energies were calculated without zero-point energy correction, ZPE. Thermodynamic properties including enthalpy of reaction $(\Delta \mathrm{H})$, Gibbs free energy $(\Delta \mathrm{G})$ and entropy $(\Delta S)$ are calculated with reference to the article written by Ochterski (17-18).

All the calculation has been conducted in the Austrian-Indonesian Centre for Computational Chemistry laboratory at the Universitas Gadjah Mada Indonesia. We have use gabedit program for generated Gaussian input file and Chemcraft program for the visualization of various molecular geometries.

\section{RESULT AND DISCUSSION}

\section{Structure of the $[M(15-C r o w n-5)]^{n+}$ Complexes}

Fig. 2 shows the structure and atomic numbering for the $15 \mathrm{C} 5-\mathrm{M}^{\mathrm{n}+}$ metal cations complexes. The geometric parameters which include bond lengths, bond angles and dihedral angles of these complexes are listed in Table 1. These parameters were obtained after the corresponding complexes optimized at the $\mathrm{rhf} /$ lanl $2 \mathrm{mb}$ level of theory.

It can be noticed from the data in Table 1 that there is an increase of the displacement of the metal cation out of the ring plane, $\mathrm{M}-\mathrm{O}$ bond length, where $\mathrm{M}$ refers to metal cations under consideration, with the increasing size of the cation diameter. The $\mathrm{C}-\mathrm{O}$ bond length of the $\mathrm{Li}^{+}, \mathrm{Na}^{+}$and $\mathrm{K}^{+}$complexes are shorter by $0.01 \AA$ than that of the $\mathrm{Zn}^{2+}, \mathrm{Cd}^{2+}$ and $\mathrm{Hg}^{2+}$ complexes. 
Table 1. Geometric parameters of the $[\mathrm{M}(15-\mathrm{Crown}-5)]^{\mathrm{n}+}$ complexes at rhf/lanl2mb

\begin{tabular}{lllllll}
\hline coordinate & $\mathbf{L i}^{+}$ & $\mathbf{N a}^{+}$ & $\mathbf{K}^{+}$ & $\mathbf{Z n}^{2+}$ & $\mathbf{C d}^{2+}$ & $\mathbf{H g}^{\mathbf{2 +}}$ \\
\hline M-O1 & 1.89 & 2.22 & 2.65 & 2.04 & 2.19 & 2.22 \\
M-O2 & 1.83 & 2.15 & 2.66 & 2.02 & 2.19 & 2.26 \\
M-O3 & 1.99 & 2.22 & 2.68 & 2.03 & 2.17 & 2.25 \\
M-O4 & 1.90 & 2.19 & 2.67 & 2.04 & 2.19 & 2.25 \\
M-O5 & 1.89 & 2.19 & 2.67 & 2.04 & 2.19 & 2.26 \\
C7-O1 & 1.43 & 1.43 & 1.44 & 1.44 & 1.44 & 1.44 \\
C8-O2 & 1.43 & 1.43 & 1.43 & 1.44 & 1.44 & 1.44 \\
C7-H11 & 1.10 & 1.10 & 1.10 & 1.10 & 1.10 & 1.10 \\
C7-H12 & 1.10 & 1.10 & 1.10 & 1.10 & 1.10 & 1.10 \\
C8-H13 & 1.10 & 1.10 & 1.10 & 1.10 & 1.10 & 1.10 \\
C8-H14 & 1.10 & 1.10 & 1.10 & 1.10 & 1.10 & 1.10 \\
C7-C8 & 1.55 & 1.55 & 1.55 & 1.56 & 1.55 & 1.56 \\
O1C7C8 & 106.0 & 107.9 & 108.0 & 107.4 & 107.4 & 108.4 \\
C7C8O2 & 104.3 & 107.3 & 107.5 & 105.9 & 107.5 & 108.7 \\
C8O2C9 & 116.9 & 113.0 & 112.0 & 117.7 & 113.4 & 114.2 \\
MO2C8 & 118.1 & 123.5 & 112.2 & 121.4 & 120,0 & 117.4 \\
MO2C9 & 120.8 & 123.5 & 108.7 & 120.5 & 120.2 & 117.0 \\
MO1C7C8 & -21.9 & 39.2 & 36.0 & -31.9 & -33.0 & 22.8 \\
MO2C8C7 & -36.9 & 18.4 & 56.4 & -24.3 & -31.1 & 36.5 \\
\hline
\end{tabular}

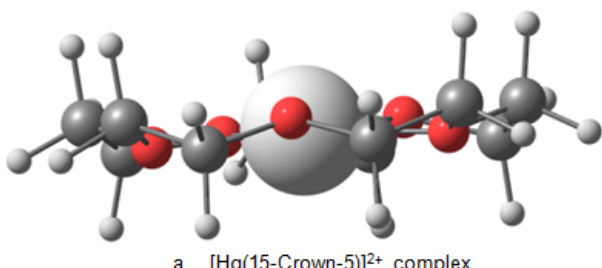

a. $[\mathrm{Hg}(15-\mathrm{Crown}-5)]^{2+}$ complex
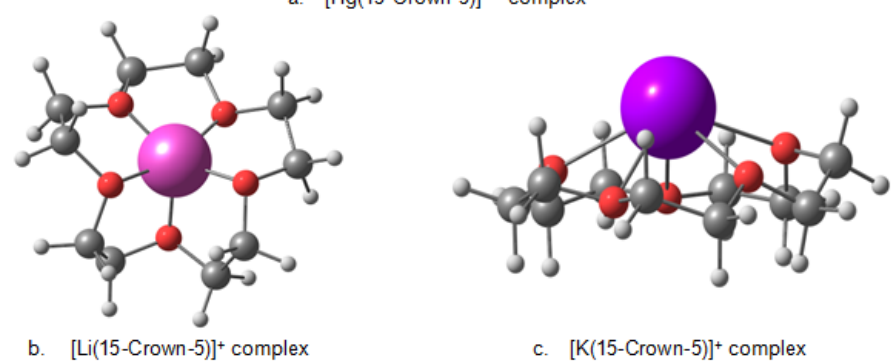

Fig 3. Three-dimensional structure of $[M(15-C r o w n-5)]^{\text {nt }}$ complexes

While the $\mathrm{C}-\mathrm{H}$ bond length is unchanged for the six complexes, the $\mathrm{C}-\mathrm{C}$ bond length of the $\mathrm{Zn}^{2+}$ and $\mathrm{Hg}^{2+}$ complexes are longer than the other complexes by 0.01 Angstrom. The $\mathrm{CCO}$ bond angles are increased by 2-4 degrees. There is a quite large decreased of the MOC bond angle for the $\mathrm{K}^{+}$cation by about $6-11$ degrees than the other complexes. This is due to the big diameter of the $\mathrm{K}^{+}$cation. In addition, there is a large increased of the MOCC dihedral angle by about 20 degrees, as the large $\mathrm{K}^{+}$to that of the other cations.

According to the experimental data, the cavity hole of the 15-crown-5 is ranged from 1.70 to 2.20 Angstrom. This cavity hole is suitable for occupancy of the $\mathrm{Na}^{+}$(1.94), $\mathrm{Cd}^{2+}(1.94)$ and $\mathrm{Hg}^{2+}(2.20)$ cations, so that all three cations are able to correctly fill in the hole cavity of the 15-crown-5 as shown in Fig. 3. For the small ions

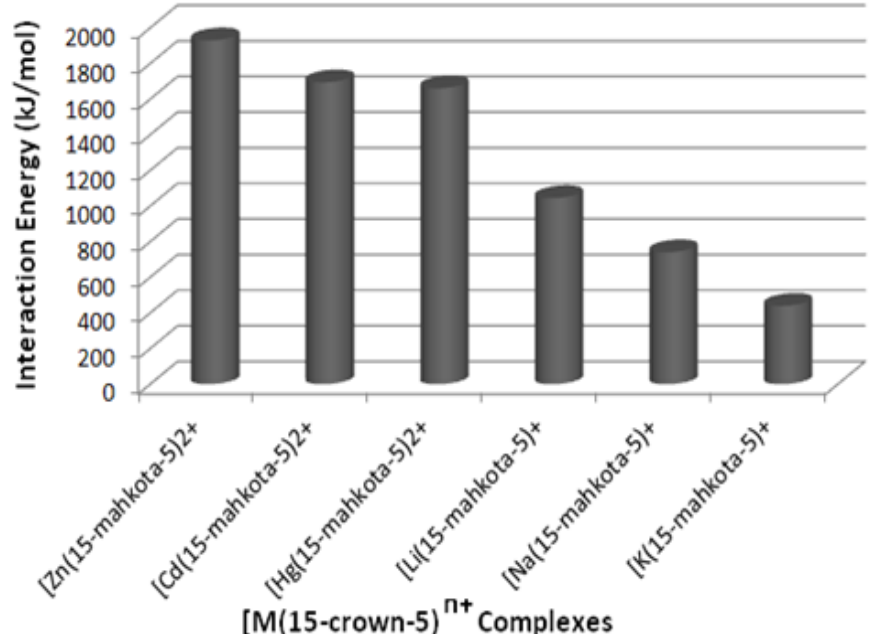

Fig 4. Interaction energies of $\left[M(15-\text { Crown-5) }]^{\text {nt }}\right.$ complexes

such as $\mathrm{Li}^{+}(1.36)$ and $\mathrm{Zn}^{2+}(1.48)$, the 15-crown-5 to be somewhat shrunken to binding on both of the cation. The largest $\mathrm{K}^{+}$cations can not get into the hole cavity so that the cation are located above the cavity ring plane and form a like pyramid complex. Threedimensional structure of $\left[\mathrm{M}(15-\text { Crown-5) }]^{\mathrm{nt}}\right.$ complexes are shown in Fig. 3.

\section{Interaction Energies of the $\left[M(15-\text { Crown-5) }]^{\text {n+ }}\right.$ Complexes}

Calculated value of interaction energies of [M(15Crown-5)] $]^{\text {nt }}$ complexes are presented in Fig. 4. The calculations were performed at the rhf/lanl $2 \mathrm{mb}$ level of theory. In can be seen that the interaction energies of the complexes are affected by the nature of the metal 
Table 2. The properties of the metal cations and their ratio to the cation diameter

\begin{tabular}{lccccccc}
\hline \multicolumn{1}{c}{ Cation } & $\mathrm{z}$ & $\mathrm{E}_{\mathrm{i}}{ }^{\prime}(\mathrm{MJ} / \mathrm{mole})$ & $\chi$ & $\mathrm{d}$ & $\mathrm{z} / \mathrm{d}$ & $\mathrm{E}_{\mathrm{i}} / \mathrm{d}$ & $\chi / \mathrm{d}$ \\
\hline $\mathrm{Li}^{+}$ & 1.00 & 0.520 & 0.98 & 1.36 & 0.735 & 0.382 & 0.721 \\
$\mathrm{Na}^{+}$ & 1.00 & 0.496 & 0.93 & 1.94 & 0.515 & 0.256 & 0.479 \\
$\mathrm{~K}^{+}$ & 1.00 & 0.419 & 0.82 & 2.66 & 0.376 & 0.158 & 0.308 \\
$\mathrm{Zn}^{2+}$ & 2.00 & 1.733 & 1.65 & 1.48 & 1.351 & 1.171 & 1.115 \\
$\mathrm{Cd}^{2+}$ & 2.00 & 1.631 & 1.69 & 1.94 & 1.031 & 0.841 & 0.871 \\
$\mathrm{Hg}^{2+}$ & 2.00 & 1.810 & 1.90 & 2.20 & 0.909 & 0.823 & 0.864 \\
\hline \multicolumn{2}{l}{ Value of $\mathrm{E}_{\mathrm{i}}$ and $\chi$ taken from Lange's Handbook of Chemistry, $15^{\text {th }}$ ed. [21]. }
\end{tabular}

cations. Generally, the interaction energies are in inverse order to the effective diameter of corresponding metal cations. In this study, the interaction energies for the 15-crown-5 complexes fall in this order: $\mathrm{K}^{+}<\mathrm{Na}^{+}<$ $\mathrm{Li}^{+}<\mathrm{Hg}^{2+}<\mathrm{Cd}^{2+}<\mathrm{Zn}^{2+}$. These results shown that in the gas phase, selectivity of the crown ether do not correlate to the matching size of crown ether cavity hole and diameter of the metal cations. For alkali metal cations, selectivity of 15-crown-5 following the order $\mathrm{Li}^{+}>\mathrm{Na}^{+}>$ $\mathrm{K}^{+}$, while for the other groups following the order $\mathrm{Zn}^{2+}>$ $\mathrm{Cd}^{2+}>\mathrm{Hg}^{2+}$.

Selectivity of crown ethers to metal cations are often interpreted based on the "best-fit" concept of the metal cation size with crown ether cavity hole. This argument seems less appropriate or not applicable to the gas phase due to the coordination of the cationoxygen crown ethers are not severely affected by the solvent. In contrast to that found in aqueous solutions, the binding energy of isolated complexes (solvent free) formed by ether 12-crown-4 (12C4), 15-crown-5 (15C5), 18-crown-6 (18C6) and 21-crown-7 (21C7) decreased monotonically with the increasing size of alkali metal cations, namely in the order $\mathrm{Li}^{+}>\mathrm{Na}^{+}>\mathrm{K}^{+}>\mathrm{Rb}^{+}>\mathrm{Cs}^{+}$ [7-8]. Qualitatively it has also been observed in experiments for non-cyclic polyether's [19].

The incompatibility of crown ethers selectivity of metal cations in the gas phase to that expected based on "best-fit" concept supports a notion of stabilization by the solvent to the complex cation-crown ethers that occur in solution. In a solution of water, hydration of the cation plays an important role. According to experimental data, the hole cavity of 15 -crown-5 is 170 up to $220 \mathrm{pm}$ [20] that fit with the size of $\mathrm{Na}^{+}$and $\mathrm{Cd}^{2+}$ which both have a diameter of $194 \mathrm{pm}$. The results of this calculation show that the interaction energy or the stability of the complexes is not directly related with the "best-fit "concept.

In order to investigate the effect of metal ionic properties, the interaction energies of the [M(15-Crown5) $]^{\text {n+ }}$ complexes were correlated with several properties of metal cations that considered in this study, including the ionic charge $(z)$, the ionization energy $\left(E_{i}\right)$, electronegativity $(\chi)$ and the diameter of the cations (d) as listed in Table 2.
Fig. 5 shows an almost linearly relationship between the interaction energies with the ratio of metal properties to the cation diameter, especially for the ratio of ionization energy to the cation diameter. This suggest that this ratio could be use to evaluate selectivity of the crown ether. The interaction energy results indicate that the nature of metal cation plays an important role in determining stability of these complexes. Also, it can be concluded that selectivity of 15-crown-5 for metal cation is the result of synergism between the charge of metal cation, ionization energy, electronegativity and cationic size effect.

\section{Selective Extraction of Metal Cations}

Extraction power of a compound is determined by the distribution coefficient between extractant and solvent. In this study the distribution coefficient of extraction $\left(K_{d}\right)$ is defined as the ratio of equilibrium constant of [M(crown ether)] complex and the equilibrium constant of hydrated complex of metal cations, $\left[\mathrm{M}\left(\mathrm{H}_{2} \mathrm{O}\right)_{x}\right]$. For metal cations complexes with 15-crown-5, there are five oxygen atoms of crown ether that can form bonds with metal cations so for the comparison, the complex of $\left[\mathrm{M}\left(\mathrm{H}_{2} \mathrm{O}\right)_{5}\right]$ was used. The equilibrium constant of reaction $\left(\mathrm{K}_{\mathrm{c}}\right)$ calculated by the equation $\Delta G^{0}=-R T \ln K_{c}$, and the extraction distribution coefficient calculated by the equation:

$K_{d}=\frac{K_{c m}}{K_{c a}}$

where $\mathrm{K}_{\mathrm{cm}}$ is the equilibrium constant for [M (15-crown5)] complexes and $\mathrm{K}_{\mathrm{ca}}$ is equilibrium constant for the $\left[\mathrm{M}\left(\mathrm{H}_{2} \mathrm{O}\right)_{5}\right]$ complex.

The results of calculation for the extraction distribution coefficients are given in Table 3 . It can be seen that none of the metal cation under consideration could to be extracted by the 15 -crown- 5 compound because all the cations has a very small distribution coefficient.

Experimentally known that for extraction of metal cations with neutral crown ether, the nature of counter anions plays an important role in determining the efficiency and selectivity of extraction. There is evident that alkali metal salts with hard anions are only poorly extracted into most organic solvent. In addition to the 

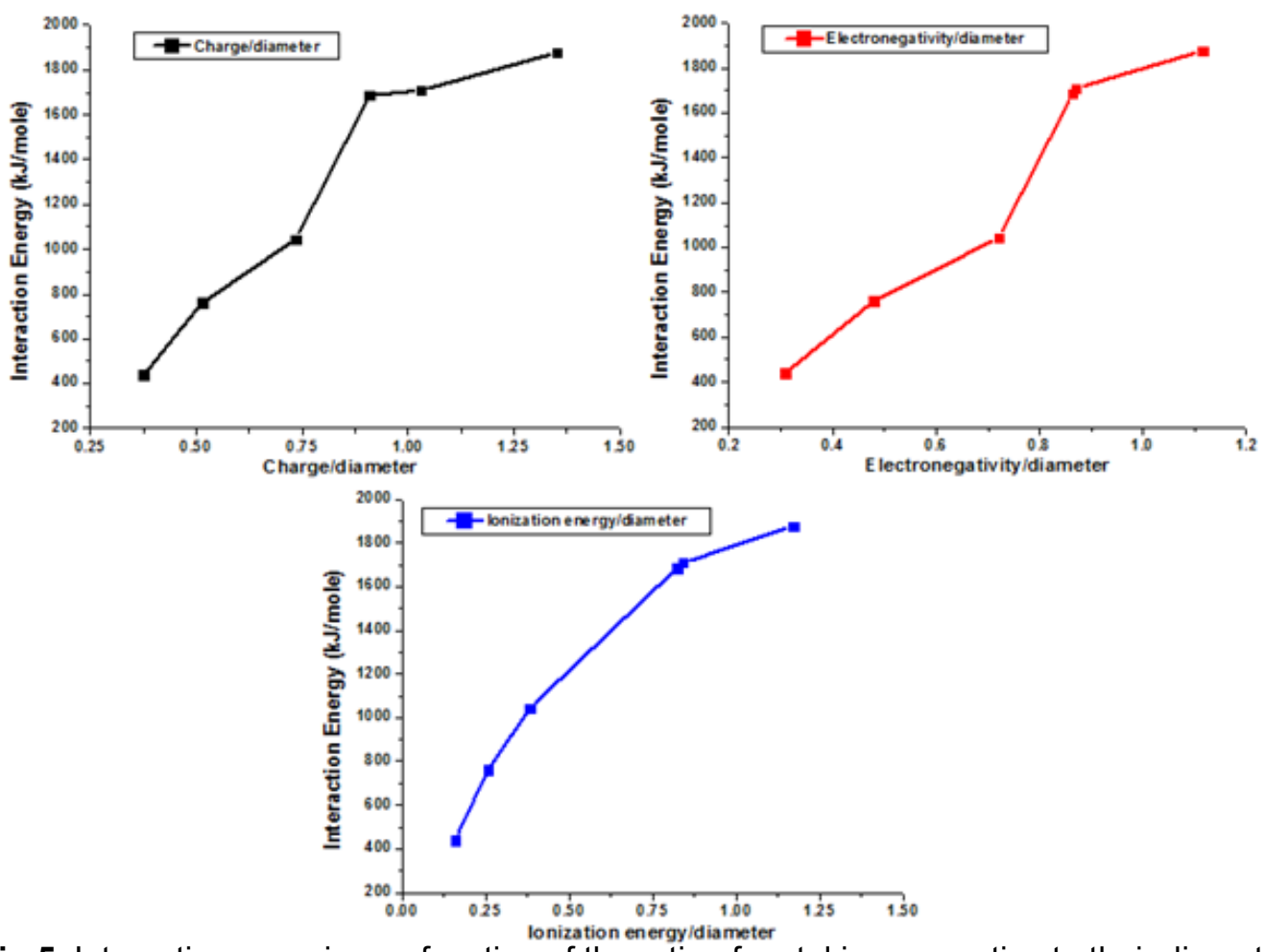

Fig 5. Interaction energies as function of the ratio of metal ion properties to their diameter

Table 3. The distribution coefficient of extraction of metal cations

\begin{tabular}{|c|c|c|c|c|c|}
\hline \multirow{2}{*}{$\begin{array}{l}\text { Metal } \\
\text { cation }\end{array}$} & \multicolumn{2}{|c|}{ [M(15-Crown-5)] complex } & \multicolumn{2}{|c|}{$\left[\mathrm{M}\left(\mathrm{H}_{2} \mathrm{O}\right)_{5}\right]$ complex } & \multirow{2}{*}{$\mathrm{K}_{\mathrm{d}}=\mathrm{K}_{\mathrm{cm}} / \mathrm{K}_{\mathrm{ca}}$} \\
\hline & $\ln K_{c m}$ & $\mathrm{~K}_{\mathrm{cm}}$ & $\ln K_{\mathrm{ca}}$ & $\mathrm{K}_{\mathrm{ca}}$ & \\
\hline $\mathrm{Li}^{+}$ & 392.36 & $2.52 \times 10^{1 / 0}$ & 478.43 & $5.99 \times 10^{201}$ & $4.20 \times 10^{-38}$ \\
\hline $\mathrm{Na}^{+}$ & 263.15 & $1.92 \times 10^{114}$ & 305.08 & $3.12 \times 10^{132}$ & $6.18 \times 10^{-19}$ \\
\hline $\mathrm{K}^{+}$ & 151.27 & $4.95 \times 10^{65}$ & 182.25 & $1.42 \times 10^{79}$ & $3.49 \times 10^{-14}$ \\
\hline $\mathrm{Zn}^{2+}$ & 705.48 & $2.43 \times 10^{306}$ & 775.74 & $1.64 \times 10^{328}$ & $3.06 \times 10^{-21}$ \\
\hline $\mathrm{Cd}^{2+}$ & 632.45 & $4.67 \times 10^{274}$ & 681.56 & $9.98 \times 10^{295}$ & $4.68 \times 10^{-22}$ \\
\hline $\mathrm{Hg}^{2+}$ & 621.41 & $7.46 \times 10^{269}$ & 661.49 & $1.91 \times 10^{287}$ & $3.91 \times 10^{-18}$ \\
\hline
\end{tabular}

nature of counter anion, the extraction of metal cations with neutral crown ethers also require the concomitant transfer of counter ionic species from the aqueous phase into the organic phase. Some improvement in extraction efficiency of metal salt by crown ether can be obtained by modification of the organic solvent medium [22], while the concomitant transfer of counter ionic species can be avoided by using proton-ionizable crown ethers [23-24]. So the result of this theoretical research in the gas phase is in line with the results of experimental research ever done before.

Theoretically, the results of this study are also consistent with previous theoretical studies conducted on the 12-crown-4 towards some metal ions with DFT methods. By using the density functional theory method, Diao and colleagues showed that the cations $\mathrm{Li}^{+}, \mathrm{Na}^{+}$, $\mathrm{K}^{+}, \mathrm{Ca}^{2+}, \mathrm{Mg}^{2+}$ and $\mathrm{Zn}^{2+}$ also could not be extracted from aqueous solution with 12-crown-4 regardless of the anion counter [25]. Therefore it is necessary to do further theoretical research, which involves a counter anions by an ab initio or DFT methods.

\section{CONCLUSION}

The structure and interaction energies of $[\mathrm{M}(15-$ crown-5) $]^{\mathrm{n}+}$ complexes where $\mathrm{M}=\mathrm{Li}^{+}, \mathrm{Na}^{+}, \mathrm{K}^{+}, \mathrm{Ca}^{2+}$, $\mathrm{Mg}^{2+}$ and $\mathrm{Zn}^{2+}$ have been determined with lanl2mb basis set at the RHF level of theory. There is a monotonic decrease in interaction energies with increasing cations size in one group accompanying the increase in $\mathrm{M}^{\mathrm{nt}}-\mathrm{O}$ bond lengths. A good positive relationship was found between the interaction energies and the ratio of the metal charge cation, ionization energy, and electronegativity to the diameter of the cation. The distribution coefficient of extraction between the crown ether and water predict that 15-crown-5 could not extract the metal cations under this study. 


\section{ACKNOWLEDGEMENT}

The Austrian-Indonesian Centre for Computational Chemistry (AIC) at Universitas Gadjah Mada Yogyakarta Indonesia is greatly acknowledged for providing the computation facility.

\section{REFERENCES}

1. Wood, D.J., Tranter, T.J., and Todd, T.A., 1995, Solvent Extr. Ion Exch., 13, 5, 829-844.

2. Blasius, E., and Niles, K.H., 1984, Radiochim. Acta, 35, 3, 173-182.

3. Pavithran, R., and Reddy, M.L.P., 2004, Radiochim. Acta, 92, 1, 31-38.

4. Ban, Y., Nomura, M., and Fujii, Y., 2002, J. Nucl. Sci. Technol., 39, 2, 156-159.

5. Saari-Nordhaus, R., Anderson, J.A., and James, M., 2004, J. Chromatogr. A, 1039, 1-2, 123-127.

6. Lamb, J.D., Christensen, J.J., Oscarson, J.L., Nielsen, B.L., Asay, B.W., and Izatt, R.M., 1980, J. Am. Chem. Soc., 102, 22, 6820-6824.

7. Maleknia, S., and Brodbelt, J., 1992, J. Am. Chem. Soc., 114, 11, 4295-4298.

8. More, M.B., Ray, D., and Armentrout, P.B., 1999, J. Am. Chem. Soc., 121, 2, 417-423.

9. Anderson, J.D., Paulsen, E.S., and Dearden, D., 2003, Int. J. Mass Spectrom., 227, 1, 63-76.

10. Hill, S.E., Feller, D., and Glendening, E.D., 1998, J. Phys. Chem. A, 102, 21, 3813-3819.

11. Hill, S.E., and Feller, D., 2000, Int. J. Mass Spectrom., 201, 1-3, 41-58.
12. Kim, H-S., 2004, J. Phys. Chem. B, 108, 31, 11753-11759.

13. Martınez-Haya, B., Hurtado, P., Hortal, A.R., Steill, J.D., Oomens, J., and Merkling, P.J., 2009, J. Phys. Chem. A, 113, 27, 7748-7752.

14. Inokuchi, Y., Boyarkin, O.V., Kusaka, R., Haino, T., Ebata, T., and Rizzo, T.R., 2011, J. Am. Chem. Soc., 133, 31, 12256-12263.

15. Kim, H.J., Shin, W.J., Choi, C.M., Lee, J.H., and Kim, N.J., 2008, Bull. Korean Chem. Soc., 29, 10, 1973-1976.

16. Yahmin, Pranowo, H.D., and Armunanto, R., 2010, Indo. J. Chem., 10, 1, 106-109.

17. Ochterski, J.W., 2000, Thermochemistry, in Gaussian, help@gaussian.com, Gaussian Inc.

18. Ochterski, J.W., Petersson, G.A., and Wiberg, K.B., 1995, J. Am. Chem. Soc., 117, 45, 11299-11308.

19. Hortal, A.R., Hurtado, P., Martınez-Haya, B., Arregui, A., and Banares, L., 2008, J. Phys. Chem. $B, 112,29,8530-8535$.

20. Gokel, G.W., and Korzeniowski, S.H., 1982, Macrocyclic Polyether Syntheses, Springer-Verlag, New York, p. 14.

21. Dean, J.A., Lange's Handbook of Chemistry, $15^{\text {th }}$ ed., 1999, McGraw-Hill, Inc. New York.

22. Marcus, Y., and Asher, L.E., 1978, J. Phys. Chem., 82, 11, 1246-1254.

23. Tu, C., Surowiec, K., and Bartsch, R.A., 2007, Tetrahedron, 63, 19, 4184-4189.

24. Tu, C., Surowiec, K. and Bartsch, R.A., 2006, Tetrahedron Lett., 47, 20, 3443-3446.

25. Diao, K-S., Wang, H-J., and Qiu, Z-M., 2009, J. Solution Chem., 38, 6, 713-724. 